Article

\title{
Dimerization of norbornene on zeolite catalysts
}

\author{
N. G. Grigor'eva*, S. V. Bubennov, L. M. Khalilov, B. I. Kutepov \\ Federal State Budget Institution of Science, Institute of Petrochemistry and Catalysis, Russian Academy of Sciences, 141 prosp. Oktyabrya, 450075 Ufa, \\ Russian Federation
}

\section{A R T I C L E I N F O}

Article history:

Received 5 September 2014

Accepted 12 November 2014

Published 20 March 2015

Keywords:

Zeolites

Norbornene

Dimerization

Bisnorbornylidenes

\begin{abstract}
A B S T R A C T
The high activity and selectivity of H-Beta and H-ZSM-12 zeolites in the dimerization of norbornene was established. The norbornene conversion reached $100 \%$ in chlorinated paraffin and argon gas medium, with a selectivity of dimer formation of $88 \%-98 \%$. Four stereo-isomers of the bis-2,2'-norbornylidene structure were identified in the dimer fraction, with the (Z)-anti-bis-2,2'norbornylidene prevailing over the others.
\end{abstract}

(C) 2015, Dalian Institute of Chemical Physics, Chinese Academy of Sciences. Published by Elsevier B.V. All rights reserved.

\section{Introduction}

The dimers of norbornene are used as a high density rocket propellant [1]. The norbornene dimer structure is a function of the nature of the catalyst and the reaction conditions. The photodimerization of norbornene in the presence of complexes of $\mathrm{Cu}(\mathrm{I})$ leading to the formation of cyclobutane compounds (Scheme 1) was first reported by Arnold et al. [2].

This reaction and the structure of the dimers formed under the influence of $\mathrm{Ag}(\mathrm{I}), \mathrm{Tl}(\mathrm{I})$, and $\mathrm{Cu}(\mathrm{II})$ triflates [3] were also studied by Trecker et al. [4] and Salomon. In the presence of $\mathrm{NiCl}_{2}\left(\mathrm{PPh}_{3}\right)_{2}$ and $\mathrm{Zn}$ powder in tetrahydrofuran, the reductive dimerization of norbornene resulted in the formation of the product 2 (Scheme 2) [5].

With other Ni-containing catalysts such as $\mathrm{NiCl}_{2} \mathrm{~L}_{2} / \mathrm{NaBH}_{4} /$ $\mathrm{ROH}$ (where $\mathrm{L}=\mathrm{PPh}_{3}, \mathrm{PBu}_{3}, \mathrm{Ph}_{2} \mathrm{P}\left(\mathrm{CH}_{2}\right)_{2} \mathrm{PPh}_{2}$ ) norbornene is dimerized to give compounds $\mathbf{3}$ and $\mathbf{4}$ (Scheme 3) [6,7].

The formation of four bis-2,2'-norbornylidene (5) stereo-isomers has been detected in the products of metathesis polymerization of norbornene catalyzed by $\mathrm{WCl}_{3}, \mathrm{MoCl}_{5}$, and
$\mathrm{ReCl}_{5}$ (Scheme 4) [1,8].

Compound $\mathbf{5}$ can be synthesized selectively enough with the catalytic complexes developed by a group of Polish scientists [9-13]. For example, the compounds in question (5) are formed on the binuclear carbonyl complex of $\left(\mathrm{CO}_{4}\right) \mathrm{W}(\mu-\mathrm{Cl})_{3} \mathrm{~W}$ -
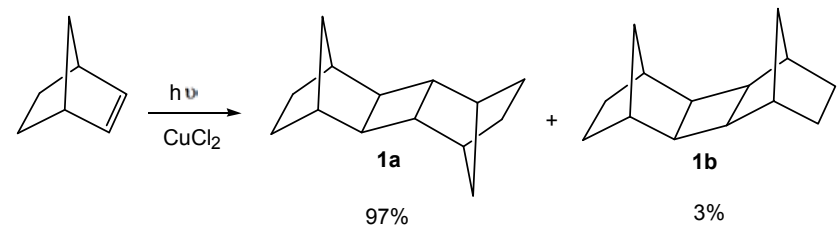

Scheme 1. Photodimerization of norbornene.

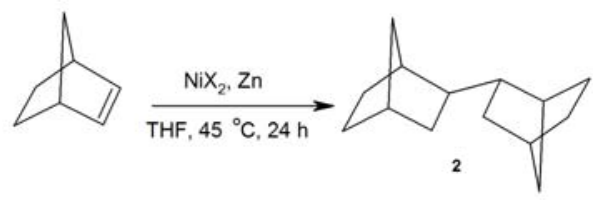

Scheme 2. Reductive dimerization of norbornene. 


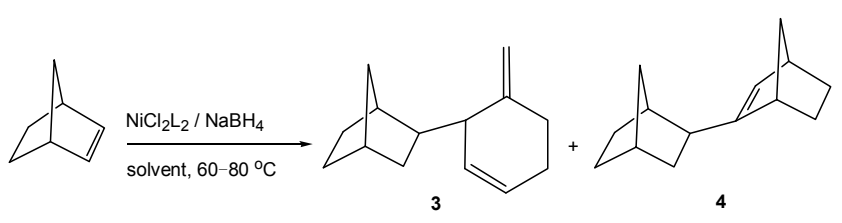

Scheme 3. Dimerization of norbornene.

$\left(\mathrm{SnCl}_{3}\right)(\mathrm{CO})_{3}$ with a yield of $68 \%[10]$.

Heterogeneous catalysts for the oligomerization of norbornene were less studied. Mobil Oil Corporation has patented two inventions related to the production of norbornene oligomers $[14,15]$. In the patent [14], the synthesis of the norbornene dimers of structure $\mathbf{1}$ was performed in the presence of reduced $\mathrm{CrO}_{3}$ on a large pore silica gel. In patent [15] for the synthesis of the norbornene dimers of the structure 5, they proposed the use of zeolites with the pore dimension of 0.5-0.8 $\mathrm{nm}$ of the ZSM family, MCM-22, PSH-3, SSZ025, and Beta zeolite. The norbornene conversion in the presence of ZSM-5 under atmospheric pressure and the boiling temperature of the olefin amounted to $80.7 \%$. $95 \%$ of the reaction mixture contained dimers and trimers formed in the weight ratio of 3.8/1. It was demonstrated that the heat of combustion of the norbornene dimers $\mathbf{5}$ was close to the heat of combustion for rocket propellant JP-10, being 41.9 and $39.4 \mathrm{MJ} / \mathrm{L}$, respectively [15].

However, the reported data did not explain the effect of the zeolite structure on the catalytic properties and whether the selectivity of the norbornene dimer formation can be altered by varying the reaction conditions.

This work reports on the structure effect of Y (FAU-type), Beta (BEA-type), ZSM-12 (MTW-type), and ZSM-5 (MFI-type) zeolites as well as the variation of the reaction conditions on the composition of the norbornene conversion products.

\section{Experimental}

\subsection{Chemicals}

For the synthesis, we used freshly distilled norbornene from Acros Company of $99 \%$ purity. The solvents, namely, nonane, chlorobenzene, methylene chloride, chloroform, carbon tetrachloride, tetrahydrofuran were purified prior to the runs by standard techniques [16].

\subsection{Catalysts}

The Y, Beta, ZSM-12, and ZSM-5 zeolites were studied in their $\mathrm{H}$ form. The $\mathrm{HY}$ zeolite with the exchange degree of $\mathrm{Na}^{+}$to $\mathrm{H}^{+}$ions of $96 \%$ was obtained by decationating of the $\mathrm{NaY}$ zeo- lite (the $\mathrm{SiO}_{2} / \mathrm{Al}_{2} \mathrm{O}_{3}$ molar ratio of 6.0) synthesized by the technique described in Ref. [17]. $\mathrm{NH}_{4}$-Beta $\left(\mathrm{SiO}_{2} / \mathrm{Al}_{2} \mathrm{O}_{3}=18.0\right)$, H-ZSM-5 $\left(\mathrm{SiO}_{2} / \mathrm{Al}_{2} \mathrm{O}_{3}=28.4\right)$ and $\mathrm{NH}_{4}-\mathrm{ZSM}-12\left(\mathrm{SiO}_{2} / \mathrm{Al}_{2} \mathrm{O}_{3}=\right.$ 34) zeolites were manufactured by OJSC "Angarsk Plant of Catalysts and Organic Synthesis". The $\mathrm{NH}_{4}$-Beta and $\mathrm{NH}_{4}-\mathrm{ZSM}-12$ zeolite samples were converted into the $\mathrm{H}$ form by calcining at $540{ }^{\circ} \mathrm{C}$. Prior to the catalytic runs, the zeolite samples were thermally treated at $540^{\circ} \mathrm{C}$ in air for $4 \mathrm{~h}$.

The catalysts were characterized by X-ray phase (XRP) and $\mathrm{X}$-ray diffraction (XRD) studies, and temperature-programmed desorption of ammonia ( $\left.\mathrm{NH}_{3}-\mathrm{TPD}\right)$. For the equilibrium adsorption capacity of the samples by the vapor of water and benzene at $20^{\circ} \mathrm{C}$, the desiccator technique was used [18].

\subsection{Dimerization of norbornene}

A glass ampoule was loaded with the thoroughly dewatered solvent, norbornene, and freshly calcined catalyst in the amount of 10-30 wt\% in Ar. The sealed ampoule was placed in the autoclave and rotated in a furnace controlled at $40-100{ }^{\circ} \mathrm{C}$. After the suspension was cooled and the catalyst filtered off, the reaction mixture was obtained followed by the separation from it of four bis-2,2'-norbornylidene isomers by vacuum distillation. The conversion of norbornene and composition of the dimer fraction were determined by gas-liquid chromatography using a HRGS 5300 Mega Series «Carlo Erba» chromatograph with a flame ionization detector. The analysis conditions were: glass capillary column of $25 \mathrm{~m}$ length, SE-30 phase, temperature of analysis $50-280{ }^{\circ} \mathrm{C}$, programmed heating of $8{ }^{\circ} \mathrm{C} / \mathrm{min}$, detector temperature of $250{ }^{\circ} \mathrm{C}$, evaporator temperature of 300 ${ }^{\circ} \mathrm{C}$, flow rate of helium carrier gas of $30 \mathrm{~mL} / \mathrm{min}$. The composition of the formed oligomers was analyzed by high performance liquid chromatography (HPLC) using a HP-1090 instrument. The analysis conditions were: Plgel $100 \AA$ polystyrene column, feed toluene flow rate of $0.8 \mathrm{~mL} / \mathrm{min}$, the ribbon speed of $1.5 \mathrm{~cm}^{-1}$, refractive index detector.

The dimers of norbornene (5a-5d) were identified using GC-MS as well as uni- and bi-dimensional NMR spectroscopy. High resolution mass spectra were recorded using a Fisons Company instrument. Its chromatograph was equipped with a DB-560 capillary quartz column (50 m), the column was heated from 50 to $320^{\circ} \mathrm{C}$ at $4{ }^{\circ} \mathrm{C} \mathrm{min}-1$, the electron impact energy was $70 \mathrm{eV} .{ }^{1} \mathrm{H}$ and ${ }^{13} \mathrm{C}$ NMR spectra were recorded with a Bruker AVANCE-400 spectrometer with the working frequency of $400.13 \mathrm{MHz}$ for the ${ }^{1} \mathrm{H}$ nuclei and $100.62 \mathrm{MHz}$ for the ${ }^{13} \mathrm{C}$ nuclei using standard $5 \mathrm{~mm}$ diameter ampoules for solutions of substances in $\mathrm{CDCl}_{3}$. Benzene- $\mathrm{d}_{6}$ and toluene- $\mathrm{d}_{8}$ were used for the internal reference. 2D homo- (COSY HH) and hetero-nuclear (HSQC, HMBS) correlation experiments were performed using the pulse field gradient techniques.

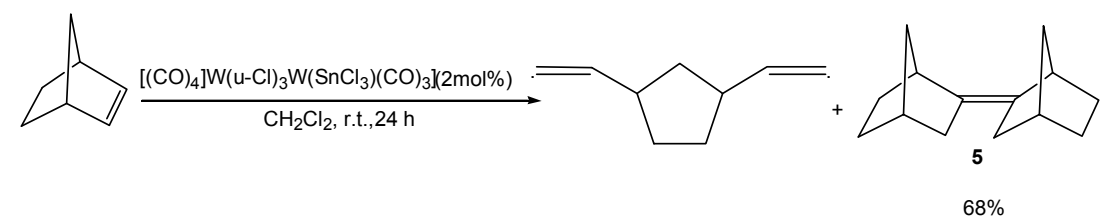

Scheme 4. Metathesis polymerization of norbornene. 
(Z), syn-Bis-2,2'-norbornylidene (5a). b.p. $82-90{ }^{\circ} \mathrm{C} / 5 \mathrm{~mm}$ Hg. ${ }^{1} \mathrm{H}$ NMR $(\delta, \mathrm{ppm}): 1.15-1.28\left(\mathrm{~m}, 4 \mathrm{H}, \mathrm{C}\left(6,6^{\prime}\right) \mathrm{H}_{2}\right) ; 1.21-1.35$ $\left(\mathrm{m}, 4 \mathrm{H}, \mathrm{C}\left(7,7^{\prime}\right) \mathrm{H}_{2}\right) ; 1.52-1.62\left(\mathrm{~m}, 4 \mathrm{H}, \mathrm{C}\left(5,5^{\prime}\right) \mathrm{H}_{2}\right) ; 1.58-2.19(\mathrm{~m}$, $\left.4 \mathrm{H}, \mathrm{C}\left(3,3^{\prime}\right) \mathrm{H}_{2}\right) ; 2.35\left(\mathrm{~m}, 2 \mathrm{H}, \mathrm{C}\left(4,4^{\prime}\right) \mathrm{H}_{2}\right) ; 2.62\left(\mathrm{~m}, 2 \mathrm{H}, \mathrm{C}\left(1,1^{\prime}\right) \mathrm{H}_{2}\right)$; ${ }^{13} \mathrm{C} \quad \mathrm{NMR}(\delta, \mathrm{ppm}): 28.55$ (C-5,5'); 28.93 (C-6,6'); 36.64 (C-4,4'); 37.08 (C-3,3'); 39.27 (C-7,7'); 41.37 (C-1,1'); 131.44 (C-2,2'). MS m/z: 188.

(E), syn-Bis-2,2'-norbornylidene (5b). b.p. 82-90 ${ }^{\circ} \mathrm{C} / 5 \mathrm{~mm}$ Hg. ${ }^{1} \mathrm{H}$ NMR $(\delta, \mathrm{ppm}): 1.15-1.28\left(\mathrm{~m}, 4 \mathrm{H}, \mathrm{C}\left(6,6^{\prime}\right) \mathrm{H}_{2}\right) ; 1.21-1.35$ $\left(\mathrm{m}, 4 \mathrm{H}, \mathrm{C}\left(7,7^{\prime}\right) \mathrm{H}_{2}\right) ; 1.52-1.62\left(\mathrm{~m}, 4 \mathrm{H}, \mathrm{C}\left(5,5^{\prime}\right) \mathrm{H}_{2}\right) ; 1.58-2.19(\mathrm{~m}$, $\left.4 \mathrm{H}, \mathrm{C}\left(3,3^{\prime}\right) \mathrm{H}_{2}\right) ; 2.35\left(\mathrm{~m}, 2 \mathrm{H}, \mathrm{C}\left(4,4^{\prime}\right) \mathrm{H}_{2}\right), 2.84\left(\mathrm{~m}, 2 \mathrm{H}, \mathrm{C}\left(1,1^{\prime}\right) \mathrm{H}_{2}\right)$; ${ }^{13} \mathrm{C}$ NMR $(\delta, \mathrm{ppm}): 28.71\left(\mathrm{C}-5,5^{\prime}\right) ; 29.73\left(\mathrm{C}-6,6^{\prime}\right) ; 36.78\left(\mathrm{C}-4,4^{\prime}\right)$; 37.02 (C-3,3'); 39.69 (C-7,7'); 41.87 (C-1,1'); 131.85 (C-2,2'). MS $\mathrm{m} / \mathrm{z}: 188$.

(Z), anti-Bis-2,2'-norbornylidene (5c). b.p. $82-90{ }^{\circ} \mathrm{C} / 5 \mathrm{~mm}$ Hg. ${ }^{1} \mathrm{H}$ NMR $(\delta, \mathrm{ppm}): 1.15-1.28\left(\mathrm{~m}, 4 \mathrm{H}, \mathrm{C}\left(6,6^{\prime}\right) \mathrm{H}_{2}\right) ; 1.21-1.35$ $\left(\mathrm{m}, 4 \mathrm{H}, \mathrm{C}\left(7,7^{\prime}\right) \mathrm{H}_{2}\right) ; 1.52-1.62\left(\mathrm{~m}, 4 \mathrm{H}, \mathrm{C}\left(5,5^{\prime}\right) \mathrm{H}_{2}\right) ; 1.58-2.19(\mathrm{~m}$, $\left.4 \mathrm{H}, \mathrm{C}\left(3,3^{\prime}\right) \mathrm{H}_{2}\right) ; 2.35\left(\mathrm{~m}, 2 \mathrm{H}, \mathrm{C}\left(4,4^{\prime}\right) \mathrm{H}_{2}\right) ; 2.58\left(\mathrm{~m}, 2 \mathrm{H}, \mathrm{C}\left(1,1^{\prime}\right) \mathrm{H}_{2}\right)$; ${ }^{13} \mathrm{C}$ NMR $(\delta, \mathrm{ppm}): 28.59$ (C-5,5'); 29.07 (C-6,6'); $36.58\left(\mathrm{C}-4,4^{\prime}\right)$; 37.16 (C-3,3'); 39.03 (C-7,7'); 41.00 (C-1,1'); 131.54 (C-2,2').

(E), anti-Bis-2,2'-norbornylidene (5d). b.p. $82-90^{\circ} \mathrm{C} / 5 \mathrm{~mm}$ Hg. ${ }^{1} \mathrm{H}$ NMR $(\delta, \mathrm{ppm}): 1.15-1.28\left(\mathrm{~m}, 4 \mathrm{H}, \mathrm{C}\left(6,6^{\prime}\right) \mathrm{H}_{2}\right) ; 1.21-1.35$ $\left(\mathrm{m}, 4 \mathrm{H}, \mathrm{C}\left(7,7^{\prime}\right) \mathrm{H}_{2}\right) ; 1.52-1.62\left(\mathrm{~m}, 4 \mathrm{H}, \mathrm{C}\left(5,5^{\prime}\right) \mathrm{H}_{2}\right) ; 1.58-2.19(\mathrm{~m}$, $\left.4 \mathrm{H}, \mathrm{C}\left(3,3^{\prime}\right) \mathrm{H}_{2}\right) ; 2.62\left(\mathrm{~m}, 2 \mathrm{H}, \mathrm{C}\left(1,1^{\prime}\right) \mathrm{H}_{2}\right), 2.80\left(\mathrm{~m}, 2 \mathrm{H}, \mathrm{C}\left(4,4^{\prime}\right) \mathrm{H}_{2}\right)$; ${ }^{13} \mathrm{C}$ NMR $(\delta, \mathrm{ppm}): 28.66\left(\mathrm{C}-5,5^{\prime}\right) ; 29.77\left(\mathrm{C}-6,6^{\prime}\right) ; 36.70\left(\mathrm{C}-4,4^{\prime}\right)$; 37.04 (C-3,3'); 39.89 (C-7,7'); 41.81 (C-1,1'); 131.95 (C-2,2').

Nortricyclane (6). b.p. $35{ }^{\circ} \mathrm{C} / 50 \mathrm{~mm} \mathrm{Hg}$. Calculated $\mathrm{C}_{7} \mathrm{H}_{10}$ (\%): C, 89.29; H, 10.71. Found (\%): C, 88.60; H, 11.40. ${ }^{1} \mathrm{H}$ NMR $(\delta, \mathrm{ppm}): 1.0(\mathrm{~s}, 1 \mathrm{H}, \mathrm{C}(3,4,5) \mathrm{H}) ; 1.2\left(\mathrm{~s}, 6 \mathrm{H}, \mathrm{C}(2,6,7) \mathrm{H}_{2}\right) ; 1.86(\mathrm{~s}$, $1 \mathrm{H}, \mathrm{C}(1) \mathrm{H}) ;{ }^{13} \mathrm{C}$ NMR $(\delta, \mathrm{ppm}): 10.3$ (C-3,4,5); 29.9 (C-1); 33.4 $(\mathrm{C}-2,6,7)$. MS $m / z: 94$.

exo-2-Norborneol (7). ${ }^{1} \mathrm{H}$ NMR $(\delta, \mathrm{ppm}): 1.02-1.05(\mathrm{~m}, 3 \mathrm{H}$, $\left.\left.\mathrm{C}(6) \mathrm{H}_{2}, \mathrm{C}(7) \mathrm{H}_{2}, \mathrm{C}(5) \mathrm{H}_{2}\right), 1.12-1.18\left(\mathrm{~m}, 2 \mathrm{H}, \mathrm{C}(3) \mathrm{H}_{2}\right), \mathrm{C}(5) \mathrm{H}_{2}\right)$, 1.36-1.51 (m, 2H, C(7) $\left.\mathrm{H}_{2}, \mathrm{C}(6) \mathrm{H}_{2}\right), 1.62-1.67$ (m, $\left.1 \mathrm{H}, \mathrm{C}(3) \mathrm{H}_{2}\right)$, 2.12-2.35 (m, 2H, C(4)H, C(1)H), 2.81(s, 1H, OH); 3.68 (d, 1H, C(2)H). ${ }^{13}$ C NMR, $\delta: 24.39$ (C-6), 29.27 (C-5), 34.38 (C-7), 35.40 (C-4), 42.37 (C-3), 44.34 (C-1), 74.95 (C-2). The spectral data match those given [19]. MS $m / z: 122$. Kovach index $I_{\mathrm{k}} 1065$.

exo-, exo-2,2'-Dinorbornyl ether (8). b.p. $108{ }^{\circ} \mathrm{C} / 3 \mathrm{~mm} \mathrm{Hg}$; $\mathrm{T}_{\text {melt }}=55^{\circ} \mathrm{C}$. Calculated $\mathrm{C}_{14} \mathrm{H}_{22} \mathrm{O}(\%): \mathrm{C}, 81.50 ; \mathrm{H}, 11.03 ; 0,7.47$. Found (\%): C, 80.12; H, 10.71. ${ }^{1} \mathrm{H}$ NMR $(\delta, \mathrm{ppm}): 0.94(\mathrm{~d}, 1 \mathrm{H}$, $\left.\mathrm{C}(6) \mathrm{H}_{2}\right) ; 1.02$ (d, 1H, C(5)H $) ; 1.04\left(\mathrm{~m}, 1 \mathrm{H}, \mathrm{C}(7) \mathrm{H}_{2}\right) ; 1.26(\mathrm{~m}, 1 \mathrm{H}$, $\mathrm{C}(3) \mathrm{H}) ; 1.41\left(\mathrm{~d}, 1 \mathrm{H}, \mathrm{C}(5) \mathrm{H}_{2}\right) ; 1.46\left(\mathrm{~d}, 1 \mathrm{H}, \mathrm{C}(6) \mathrm{H}_{2}\right) ; 1.50(\mathrm{~m}, 1 \mathrm{H}$, $\left.\mathrm{C}(7) \mathrm{H}_{2}\right) ; 1.50\left(\mathrm{~m}, 1 \mathrm{H}, \mathrm{C}(3) \mathrm{H}_{2}\right) ; 2.23(\mathrm{~s}, 1 \mathrm{H}, \mathrm{C}(4) \mathrm{H}) ; 2.25(\mathrm{~s}, 1 \mathrm{H}$, $\mathrm{C}(1) \mathrm{H}) ; 3.35(\mathrm{~m}, 1 \mathrm{H}, \mathrm{C}(2) \mathrm{H}) ;{ }^{13} \mathrm{C}$ NMR $(\delta, \mathrm{ppm}): 24.8(\mathrm{C}-6)$,
28.71 (C-5); 34.93 (C-7); 35.26 (C-4); 40.17, 40.31 (2C, C-3); 40.9, 41.12 (2C, C-1); 79.71, 80.19 (2C, C-2). The spectral data match those given $[12,19]$. MS $m / z: 206$.

\section{Results and discussion}

\subsection{Characterization of the zeolite catalysts}

The HY, HBeta, HZSM-12, HZSM-5 zeolites investigated in this work were the FAU, BEA, MTW, MFI structural types. They differed in their crystal structure, framework atom ratio, and acidic properties. HY and HBeta zeolites possess the largest pores structure, and HZSM-5 zeolite has the smallest [20]. The physicochemical properties of the zeolites studied are given in Table 1.

According to the XRP and XRD data, and the adsorption characteristics, all the zeolite samples were characterized by a crystallinity degree close to $100 \%$. The acidity of the zeolites obtained by $\mathrm{NH}_{3}$-TPD showed two peaks characterizing the "weak" acid sites with the maximum temperature $T_{\max }$ at $100-350{ }^{\circ} \mathrm{C}$ and the "strong" acid sites with the maximum temperature $T_{\max \text { II }}$ located above $350{ }^{\circ} \mathrm{C}$ (Table 1 ).

The concentration of the important "strong" acid sites showed its maximum in the HY zeolite sample. On moving to the HBeta, HZSM-5, and HZSM-12 zeolite samples, both the "strong" acid site concentration and total concentration decreased. The strength of the "strong" acid site in the zeolites was evaluated by the shift of the high temperature maximum $T_{\max }\left(T_{\max \text { II }}=450{ }^{\circ} \mathrm{C}\right)$ in the thermal desorption. The strength appeared to be approximately the same for the high silica HBeta, HZSM-5, and HZSM-12 zeolites. The weaker acid sites present in the HY zeolite $\left(T_{\max I I}=400{ }^{\circ} \mathrm{C}\right)$ matched the known reference data [21-23].

\subsection{Effect of the zeolite structure}

In the chloroalkane and argon gas medium, the zeolite catalysts induced the conversion of norbornene into the inner ring formation product such as nortricyclane (6), and oligomerization products: dimers $(\mathbf{5 a}-\mathbf{5 d})$, and trimers as shown in Scheme 5.

The catalyst activity was evaluated by the norbornene conversion at $60^{\circ} \mathrm{C}$ after $5 \mathrm{~min}$ (Table 2).

The maximum conversion of norbornene of $80 \%$ was observed on HBeta zeolite. The minimum conversion of $2 \%$ was

Table 1

Physicochemical properties of the zeolites.

\begin{tabular}{|c|c|c|c|c|c|c|c|c|c|c|}
\hline \multirow{3}{*}{ Sample } & \multirow{3}{*}{ Structure } & \multirow{3}{*}{$\begin{array}{l}\beta^{a} \\
(\%)\end{array}$} & \multirow{3}{*}{$\begin{array}{c}\mathrm{SiO}_{2} / \\
\mathrm{Al}_{2} \mathrm{O}_{3} \text { ratio }\end{array}$} & \multirow{2}{*}{\multicolumn{2}{|c|}{$\begin{array}{c}\text { Equilibrium adsorption } \\
\text { capacity }^{\mathrm{b}} \\
\end{array}$}} & \multicolumn{5}{|c|}{ Acidic properties } \\
\hline & & & & & & \multicolumn{2}{|c|}{$T_{\max }\left({ }^{\circ} \mathrm{C}\right)$} & \multicolumn{3}{|c|}{ Concentration of the acid sites ${ }^{\mathrm{c}}(\mathrm{mol} / \mathrm{g})$} \\
\hline & & & & Water & Benzene & $\mathrm{I}$ & II & $\mathrm{C}_{\mathrm{I}}$ & $\mathrm{C}_{\mathrm{II}}$ & $\mathrm{C}$ \\
\hline$\overline{\mathrm{HY}}$ & 12-ring; $7.4 \times 7.4 \AA$ & 100 & 6 & 0.28 & 0.32 & 250 & 400 & 622 & 560 & 1182 \\
\hline HBeta & 12-ring; 5.6 ×5.6 $\AA$; $6.6 \times 7.3 \AA$ & 100 & 18 & 0.26 & 0.32 & 280 & 450 & 530 & 340 & 870 \\
\hline HZSM-12 & 12-ring; $5.6 \times 6.0 \AA$ & 100 & 34 & 0.15 & 0.16 & 300 & 450 & 410 & 260 & 670 \\
\hline HZSM-5 & 10-ring; $5.1 \times 5.5 \AA ; 5.3 \times 5.6 \AA$ & 100 & 28 & 0.05 & 0.20 & 300 & 450 & 320 & 300 & 620 \\
\hline
\end{tabular}

${ }^{\text {a crystallinity degree; }}$

${ }^{\mathrm{b}}$ conditions: $20^{\circ} \mathrm{C}, P / P_{\mathrm{s}}=0.8$;

${ }^{\mathrm{c}} \mathrm{C}_{\mathrm{I}}, \mathrm{C}_{\mathrm{II}}$, and $\mathrm{C}$ denote the concentration of "weak" (I), "strong" (II) acid sites and total concentration. 

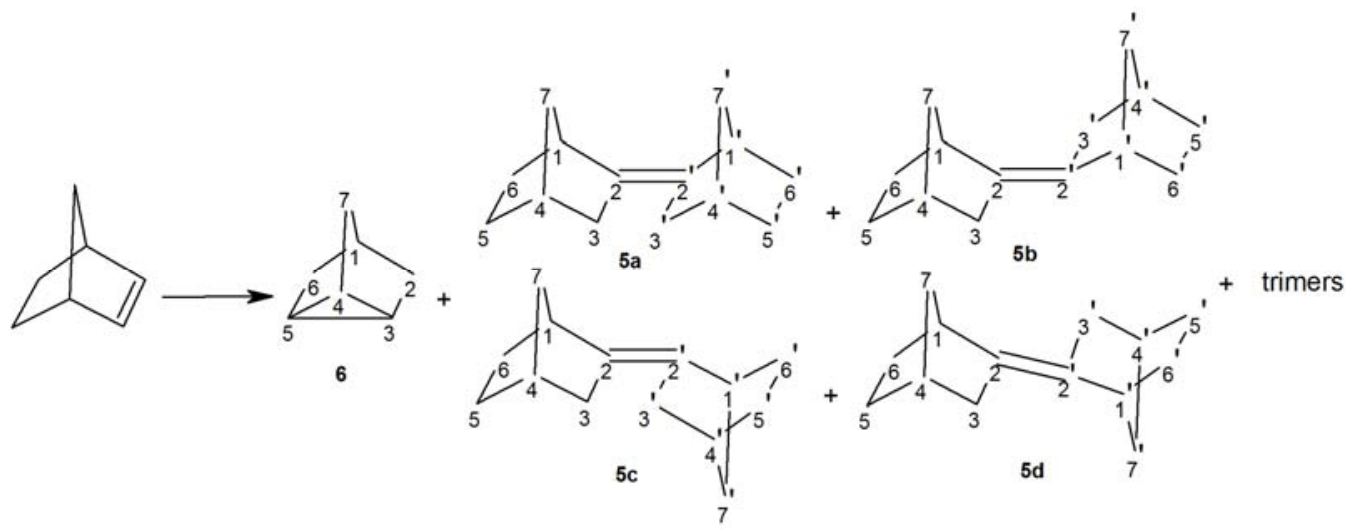

Scheme 5. Norbornene dimerization over a zeolite catalyst in inert medium.

on HZSM-5 zeolite. Under the action of HY and HZSM-12 zeolites, the norbornene conversion reached $68 \%$ and $63 \%$, respectively. At $80{ }^{\circ} \mathrm{C}$ reacted for $1 \mathrm{~h}$, the conversion of norbornene was close to $100 \%$ on all catalysts.

The comparison of the results and acidic properties of the zeolite catalysts allowed us to observe that norbornene was converted most quickly on HBeta, HY, and HZSM-12 zeolites possessing both a high concentration of "strong" acid sites and wide pores.

The composition of the reaction products including the cyclization-to-oligomerization product ratio was also affected by the structural type. As seen in Table 2, the most selective norbornene dimer formation occured in the presence of HZSM-12 (93\%-98\%) and HBeta (89\%-93\%) zeolites.

When using HY zeolite, a significant $40 \%-43 \%$ quantity of nortricyclane was present in the reaction mixture, and nortricyclane was the major reaction product on HZSM-5 zeolite.

What stands out is that on HZSM-12 and HZSM- 5 zeolites that belong to the same medium pore pentasil family and possessing close acidic properties, different compounds were prevalent in the reaction products. The major norbornene conversion product on HZSM-5 zeolite was nortricyclane (6), whereas on HZSM-12 zeolite it was the norbornene dimers. This may be attributed to the difference in the topology of the zeolite crystal structure (Table 1). The straight channels 0.56-0.67 $\mathrm{nm}$ in diameter in the HZSM-12 zeolite do not prevent norbornene dimer formation, whereas in the more tight HZSM-5 zeolite channels, the less bulky nortricyclane molecules were formed and diffuse more easily than the norbornene dimer molecules. The diffusion of the latter was more difficult.
The low selectivity of HY zeolite in the reaction of norbornene dimerization and its specific role in the norbornene isomerization process may be associated with the heterogeneity of the acidic centers in the catalyst or with the presence of the active centers promoting the isomerization reaction.

On all the zeolite catalysts, the dimer $\mathbf{5 d}$ (57\% of the dimer total) dominated the four isomers, the dimer 5a was the least $(0.7 \%)$. This isomer distribution was probably associated with the higher thermodynamic stability of compound $\mathbf{5 d}$.

\subsection{Effect of the reaction conditions}

The inert atmosphere and thorough dewatering of the catalyst and reagents used are very important for norbornene dimerization to occur. In an atmosphere of air, oxygen-containing compounds appear in the norbornene conversion products, namely, 2-norborneol (7) and dinorbornyl ether (8). In this case the conversion scheme of norbornene was shown in Scheme 6.

Evidently, 2-norborneol (7) is formed as a result of the interaction of norbornene with water adsorbed in the zeolite. The dehydration of the norbornyl alcohol or its interaction with norbornene gives dinorbornyl ether (8) (Scheme 7).

The increasing of reaction time (up to $1 \mathrm{~h}$ ) and the temperature (to $80{ }^{\circ} \mathrm{C}$ ) and the catalyst concentration (to $20 \mathrm{wt} \%$ ) resulted in the almost complete conversion of the norbornene, although the selectivity of the formation of the dimers of norbornene was decreased.

The comparison of the results obtained with the zeolite Beta and ZSM-12 showed the high efficiency of these catalysts in the

Table 2

Dimerization of norbornene in the presence of the zeolite catalysts.

\begin{tabular}{|c|c|c|c|c|c|c|c|}
\hline \multirow{2}{*}{ Catalyst } & \multirow{2}{*}{$\begin{array}{c}\text { Catalyst loading } \\
\text { (wt\%) }\end{array}$} & \multirow{2}{*}{$\begin{array}{c}\mathrm{T} \\
\left({ }^{\circ} \mathrm{C}\right)\end{array}$} & \multirow{2}{*}{$\begin{array}{l}\text { Reaction time } \\
\text { (min) }\end{array}$} & \multirow{2}{*}{$\begin{array}{c}\text { Conversion } \\
(\%)\end{array}$} & \multicolumn{3}{|c|}{ Selectivity (\%) } \\
\hline & & & & & 6 & $5 a-5 d$ & Trimers \\
\hline$\overline{\mathrm{HY}}$ & 10 & 60 & 5 & 68 & 40 & 58 & 2 \\
\hline HBeta & 10 & 60 & 5 & 80 & 4 & 93 & 3 \\
\hline HZSM-12 & 10 & 60 & 5 & 63 & 2 & 98 & - \\
\hline HZSM-5 & 10 & 60 & 5 & 2 & 98 & 2 & - \\
\hline HBeta & 10 & 60 & 60 & 93 & 4 & 90 & 6 \\
\hline HBeta & 20 & 80 & 60 & 100 & 5 & 89 & 6 \\
\hline HZSM-12 & 10 & 60 & 60 & 78 & 2 & 95 & 3 \\
\hline HZSM-12 & 20 & 80 & 60 & 97 & 4 & 93 & 3 \\
\hline
\end{tabular}

Reaction conditions: $\mathrm{CH}_{2} \mathrm{Cl}_{2}$ solvent, the initial concentration of norbornene in the solvent $\left[\mathrm{M}_{0}\right]=3.5 \mathrm{~mol} / \mathrm{L}$. 


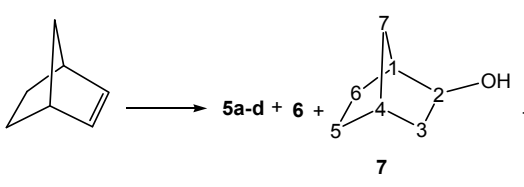<smiles></smiles>

Scheme 6. Conversion of norbornene over zeolite catalysts in air.<smiles></smiles>

Scheme 7. Conversion of norborneol over zeolite catalysts.

synthesis of the dimers (5). It should be noted that the selectivity of the formation of dimers (5) in the presence of zeolite HBeta and HZSM-12 exceeded the selectivity attained by the action of metal complex catalysts [10].

Similar to the reaction in the atmosphere of Ar, the highest $60 \%-73 \%$ yield of the norbornene dimers was obtained on the HZSM-12 and HBeta zeolites. On the HY and HZSM-5 zeolites, the isomerization of norbornene occurred resulting in the formation of nortricyclane in the yield amounts of $60 \%$ and $66 \%$, respectively.

The yields of the alcohol (7) and ether (8) were markedly increased when water was added into the reaction mixture in the amount of $\sim 1 \mathrm{~mol}$ per $1 \mathrm{~mol}$ of norbornene (Table 3 ).

In this case, the maximum activity was with the HBeta zeolite where the norbornene conversion was $\sim 100 \%$, and the selectivity of dinorbornyl ether formation was 99.3\%. The transformation of norbornene in the presence of the zeolite catalysts was studied not only in chloroalkanes $\left(\mathrm{CCl}_{4}, \mathrm{CHCl}_{3}\right.$, $\mathrm{CH}_{2} \mathrm{Cl}_{2}$ ), but also in other solvents, namely, chlorobenzene, isooctane, and aliphatic alcohols (Table 4).<smiles>C1=CC2CCC1C2</smiles><smiles>Clc1ccccc1</smiles>

zeolite $5 a-5 d+$ $81 \%$<smiles></smiles>

Scheme 8. Tranformation of norbornene on HBeta zeolite in chlorobenzene.

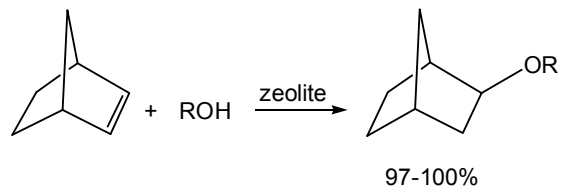

$\mathrm{R}=\mathrm{Me}, \mathrm{Et}, \mathrm{Pr}, \mathrm{Bu}, \mathrm{Hex}, \mathrm{Oct}, \mathrm{Cyclohexyl}, \mathrm{Benzyl}$

Scheme 9. Interaction of norbornene with alcohols over zeolite catalysts.

Beside the oligomerization of norbornene in chlorobenzene, the formation of chloronorbornylbenzenes was also observed (Scheme 8).

The aliphatic alcohols ROH were reagents as well. Therefore alkoxynorbornanes were the major reaction products (Scheme 9).

The conversion of norbornene in isooctane in the presence of the catalysts occurred with the formation of nortricyclane and oligomers. Dimers dominated among the latter in the amount of $75 \%-95 \%$.

The comparison of the runs showed that the most selective norbornene dimer formation occurred in chloroalkanes (Table $2,4)$.

\section{Conclusions}

From studies of the catalytic properties of HY, HBeta, HZSM-12, and HZSM-5 zeolite catalysts that differ in structure

Table 3

Interaction of norbornene with water on the zeolites.

\begin{tabular}{|c|c|c|c|c|c|c|c|c|}
\hline \multirow{2}{*}{ Catalyst } & \multirow{2}{*}{$\begin{array}{c}\text { Catalyst loading } \\
(\mathrm{wt} \%)\end{array}$} & \multirow{2}{*}{$\begin{array}{l}\text { Reaction time } \\
\text { (h) }\end{array}$} & \multirow{2}{*}{$\begin{array}{c}T \\
\left({ }^{\circ} \mathrm{C}\right)\end{array}$} & \multirow{2}{*}{$\begin{array}{c}\text { Conversion } \\
(\%)\end{array}$} & \multicolumn{4}{|c|}{ Selectivity (\%) } \\
\hline & & & & & 6 & 7 & 8 & $5 a-5 d$ \\
\hline$\overline{\mathrm{HY}}$ & 20 & 1 & 60 & 17 & 27 & 18 & 55 & - \\
\hline HBeta & 20 & 1 & 60 & 100 & 1 & - & 99 & - \\
\hline HZSM-12 & 20 & 1 & 60 & 50 & 19 & 4 & 73 & 4 \\
\hline HZSM-5 & 50 & 10 & 60 & 5 & 37 & 25 & 38 & - \\
\hline
\end{tabular}

Table 4

Transformations of norbornene in different solvents.

\begin{tabular}{|c|c|c|c|c|c|c|c|c|}
\hline \multirow{2}{*}{ Catalyst } & \multirow{2}{*}{$\begin{array}{c}\text { Catalyst loading } \\
\text { (wt\%) }\end{array}$} & \multirow{2}{*}{$\begin{array}{c}T \\
\left({ }^{\circ} \mathrm{C}\right) \\
\end{array}$} & \multirow{2}{*}{ Solvent } & \multirow{2}{*}{$\begin{array}{c}\text { Conversion } \\
(\%)\end{array}$} & \multicolumn{4}{|c|}{ Selectivity (\%) } \\
\hline & & & & & 6 & $5 a-5 d$ & Trimers & $\operatorname{Pr}$ \\
\hline$\overline{\mathrm{HY}}$ & 10 & 100 & isooctane & 90 & 57 & 41 & 2 & - \\
\hline HBeta & 10 & 80 & chlorobenzene & 96 & - & 81 & 2 & 17 \\
\hline HBeta & 30 & 80 & isooctane & 99 & 15 & 74 & 11 & - \\
\hline HBeta & 10 & 40 & methanol & 100 & - & - & - & 100 \\
\hline HZSM-12 & 10 & 100 & isooctane & 94 & 19 & 77 & 4 & - \\
\hline HZSM-12 & 30 & 40 & carbon tetrachloride & 100 & 6 & 88 & 6 & - \\
\hline
\end{tabular}

Reaction conditions: initial concentration of norbornene in the solvent $\left[\mathrm{M}_{0}\right]=3.5 \mathrm{~mol} / \mathrm{l}$, reaction time $1 \mathrm{~h} ; \mathrm{Pr}-$ Products of the interaction norbornene with the solvent. 


\section{Graphical Abstract}

Chin. J. Catal., 2015, 36: 268-273 doi: 10.1016/S1872-2067(14)60251-5

\section{Dimerization of norbornene on zeolite catalysts}

N. G. Grigor'eva*, S. V. Bubennov, L. M. Khalilov, B. I. Kutepov

Institute of Petrochemistry and Catalysis, Russian Academy of Sciences, Russian Federation

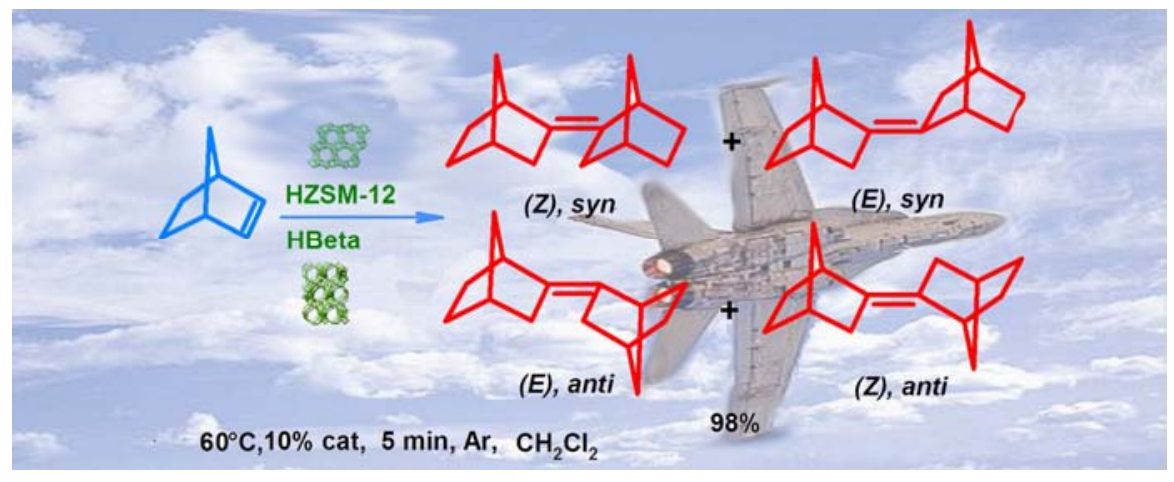

The high catalytic efficiency of H-Beta and H-ZSM-12 zeolites in producing bisnorbornylidenes by the dimerization of norbornene gave a norbornene conversion of $100 \%$ and a selectivity of dimer formation of $88 \%-98 \%$.

and acidic properties, the high activity and selectivity of HBeta and HZSM-12 zeolites for norbornene dimerization was found. The selectivity for the bis-2,2'-norbornylidene dimer structure formation reached $88 \%-98 \%$. Among the four stereoisomers of bis-2,2'-norbornylidene, the fraction of (E), anti-bis-2,2'-norbornylidene, was $57 \%$. This was probably due to the higher thermodynamic stability of the compound. In a reaction medium containing water vapor, norbornene formed norbornyl alcohol and dinorbornyl ether. The solvents most suitable for the selective production of norbornene dimers are the chlorinated paraffins, namely, methylene chloride, carbon tetrachloride, or chloroform.

\section{References}

[1] Eychenne P, Perez E, Rico I, Bon M, Lattes A, Moisand A. Colloid Polym Sci, 1993, 271: 1049

[2] Arnold D R, Trecker D J, Whipple E B. J Am Chem Soc, 1965, 87: 2596

[3] Bruno J W, Marks T J, Lewis F D. J Am Chem Soc, 1982, 104: 5580

[4] Trecker D J, Foote R S, Henry J P, McKeon J E. J Am Chem Soc, 1966, 88: 3021

[5] Huang D J, Cheng C H.J Organomet Chem, 1995, 490: C1

[6] Tenaglia A, Terranova E, Waegell B. J Mol Catal, 1987, 40: 281

[7] Dzhemilev U M, Khusnutdinov R I, Galeev D K, Toltikov G A. Iz vestiya Akademii Nauk SSSR, 1979: 910

[8] Nelsen S F, Reinhardt L A.J Phys Org Chem, 2001, 14: 847

[9] Malinowska A, Czelusniak I, Gorski M, Szymanska-Buzar T. J Mol
Catal A, 2005, 226: 259

[10] Gorski M, Kochel A, Szymanska-Buzar T. J Organomet Chem, 2006, 691: 3708

[11] Malinowska A, Kochel A, Szymanska-Buzar T. J Organomet Chem, 2007, 692: 3994

[12] Zyder M, Kochel A, Szymanska-Buzar T. J Organomet Chem, 2009, 694: 4196

[13] Szymanska-Buzar T. Coord Chem Rev, 2005, 249: 2195

[14] Wu M M, Xiong Y. US Patent 5545 790. 1996

[15] Audeh C A, Boulton J R, Kremer R A, Xiong Y. US Patent 5461181. 1995

[16] Gordon A J, Ford R A. The Chemist's Companion, A Handbook of Practical Data, Techniques and References. New York, London, Sydney, Toronto: A Wiley-Interscience Publication, 1972. Russian Edition: Moscow, Mir, 1976. 543

[17] Pavlov M L, Levinbuk M I, Baklanov V B, Smirnov V K, Bodry A B, Vidineev G A, Surkova L V, Dzhemilev U M. RU Patent 2151739. 2000

[18] Kel'tsev N V. The Fundamentals of the Adsorption Engineering. Moscow: Chemistry, 1984. 592

[19] Whitesell J K, Minton M A. Stereochemical Analysis of Alicyclic Compounds by C-13 NMR Spectroscopy. London, New York: Chapman and Hall, 1988. 231

[20] Baerlocher Ch, McCusker L B, Olson D H. Atlas of Zeolite Framework Types. 6th Ed. Amsterdam: Elsevier, 2007. 392

[21] Katada N, Suzuki K, Noda T, Sastre G, Niwa M. J Phys Chem C, 2009, 113: 19208

[22] Suzuki K, Noda T, Katada N, Niwa M. J Catal, 2007, 250: 151

[23] van Santen R A, Kramer G J. Chem Rev, 1995, 95: 637 